\title{
UNIVERSITYOF
}

FORWARD

THINKING

WESTMINSTER用

WestminsterResearch

http://www.westminster.ac.uk/westminsterresearch

Games People Play: The Collapse of "Masculinities" and the Rise

of Masculinity as Spectacle

Ridge, Damien T.

This is a pre-publication version of a book chapter to be published in: Barry, J.A., Kingerlee, R., Seager, M. and Sullivan, L. (eds.) The Palgrave Handbook of Male Psychology and Mental Health, Palgrave, pp. 205-225.

The final definitive version is available from the publisher at:

https://dx.doi.org/10.1007\%2F978-3-030-04384-1 11

The WestminsterResearch online digital archive at the University of Westminster aims to make the research output of the University available to a wider audience. Copyright and Moral Rights remain with the authors and/or copyright owners.

Whilst further distribution of specific materials from within this archive is forbidden, you may freely distribute the URL of WestminsterResearch: ((http://westminsterresearch.wmin.ac.uk/)).

In case of abuse or copyright appearing without permission e-mail repository@westminster.ac.uk 


\section{Games people play: The collapse of "masculinities" and the rise of masculinity as spectacle}

\section{Damien Ridge}

\section{Introduction}

Perspective is important. When Andy Warhol produced an art piece of 13 police mug shots of 'Thirteen Most Wanted Men' for the New York World's Fair in 1964, the work was hurriedly painted over by concerned authorities before the public could view it. It was only years later that the Warhol's subversive (homoerotic) gaze on the FBI list was more widely appreciated (Crimp 1999, Siegel 2003). I begin with this story because it points to key issues I want to take up in this chapter, in particular, the importance of 'audience' and different readings when it comes to masculinity. While current theory tends to locate masculinity in the actors, what if it is better located in the audience? What if masculinity was better understood as a kind of public spectacle? In addition, there are the naturally subversive elements of gender (e.g. think of drag performances); the game-like nature of masculinity (men might feel compelled to play along with expectations of masculinity - think of brutal playground expectations on boys - but it doesn't mean they are not aware of its inauthenticity); and the inevitable - but less discussed link - with sexuality (see below).

While many feminist scholars - for good historical reason - want to focus our attention on patriarchy, the power of men over women (and subordinated men), the everyday lived reality for men can seem at odds with this discourse on masculinity. As was demonstrated in the successful war on facts by Donald Trump to get elected, it appeared that many deprived white heterosexual men did not consider themselves to have power, they were living in a hopeless place, and rejected the world order as espoused by elites. With little comprehension of the kind of patriarchal power middle-class feminists discuss (Lamont, Park et al. 2017), less affluent men (and women) long forgotten by mainstream elites -registered their anger and frustration with the status quo by electing a demagogic figure who used calculated chaos to defeat liberals (Steinberg, Page et al. 2018). Long before the Brexit and Trump political eruptions of 2016, there were men involved in the men's movement (Farrell 1993), and those who had experienced sexual assault (Stemple 2008), for example, who felt frustrated and left out by prevailing liberal discourses. Additionally, in a lived way, men subjectively experience their masculinity in ways which do not resonate with feminist discourses. For instance, in everyday life, men are more likely to locate their masculinity in their body, particularly in their penis (Potts 2000), and fail to recognise a competitive social-wide system that dominates women as outlined by hegemonic masculinity (Connell 1995). Given the perilous state of the world, it is more urgent than ever to understand how differing vantage points on the public spectacle of masculinity can be better understood. 
Taking into account the disparate views of masculinity in the literature (as outlined below), an alternative approach is to take as a starting point that masculinity is meant to be interpreted in different ways. For instance, men themselves frequently have a deep understand of the game-like nature of masculinity as intimated above, i.e. the idea of other realities behind gendered performances, and the use of "masculinity" to achieve some kind of purpose socially. Thus masculine-based charisma, for instance, might be used by gang leaders to attract members and build a power base (Kadir 2012). Or particular zones of the masculinised body (Graham 1998), or motions of the male body, could be used to convey something about masculinity, like power and sex (McClelland 2002). But as it is a game, not all audience members will notice - or be affected by - the erotic dimensions of masculinity. It is entirely possible that some observers might not consciously register masculinity at all in certain situations. The important point here is that to a large extent, masculinity is in the eye of the beholder, and it needs to be activated at some level, consciously or less consciously.

In this chapter, I will outline the roots of this masculine "gaming" approach. Here, I argue that gender has elements of spectacle, of "virtual reality," in that it is conjured up in the minds of social participants, it is not just an interior quality, nor a social system. Masculinity is not a thing that will resonate with people in the same way, where the influence of gender has to compete with other social things happening at any given time. Thus, masculinity could be understood as something that emerges in social participation, through varying interpretations, and in competition with other dimensions like ethnicity, social class and so, i.e. it is grounded in intersectionality.

As in any virtual reality game, there is a biological substrate from which the reality (masculinity) arises: You cannot have a virtual reality without bodies engaged. Men, for example, know that it helps to have the right kind of body for conveying masculinity, where muscular endomorphic bodies are generally at an advantage over ectomorphic ones (Wienke 1998). It is not just the male body, but the ways in which it is deployed, as well as the use of objects, that are important. Men "use their bodies as emotional and sensual instruments" (p.137) (Gorman-Murray 2013). For example, bodies are used as a way of striking a work/life balance, where home can provide a refuge from the exhausting public masculine performance. As one man put it (p. 141), "It is important for me to get changed as soon as I get home" so as to put away the costume and become a "homebody". Boys are acutely aware of gendered games from an early age, and they know about the superficiality of masculinity (Chu 2005). There are aware of their authentic feelings lurking behind the game playing, for example, they are aware of their insecurities and anxieties behind the facade. But similarly, men playing the masculinity game can easily become divorced from their authenticity, finding it difficult to know what they feel (Levant, Richmond et al. 2003). Playing the game without insight in this way can mean men's feelings become alien, frightening territory, with temptations to find short-term ways to manage them, like substance use (Lomas, Cartwright et al. 2013). Masculine gaming, as outlined at the end of this chapter, attempts to take into account not only the performative aspect of masculinity, but also the subjectivities of men themselves (frequently 
neglected in theories of masculinity), not to mention the different readings of masculinity that inevitably emerge in the playing of gendered games.

\section{Historical gender theory and hegemony}

Once, masculinity was considered just an inevitable outcome of biology. However, biology did not explain why women were relegated to housekeeping post World War 2 after doing the same jobs as men during the war (Annandale and Clark 1996). In the $20^{\text {th }}$ Century, 'sex role theory' was developed to explain expectations on people to play a role, depending on their gender. For example, the traits expected of men (e.g. toughness, independence, rationality) were quite different to those expected of women (e.g. nurturing, emotional) (Harrison and Lynch 2005). But sex role theory failed to explain why society had such expectations on men and women in the first place, and alternative theories were put forward (Connell 1987). Second wave feminism from the 1960s began to tackle social problems facing women, including the need to improve reproductive rights, address domestic violence, as well as wider sexual harassment and violence.

In the early $20^{\text {th }}$ Century, Antonio Gramsci developed the idea of hegemony to describe the wielding of political power by the upper classes, manipulating values and social mores to justify their power and the status quo (Gramsci 1998). Australian sociologist, Raewyn Connell, subsequently transported this idea of cultural hegemony to the area of gender. She developed a social wide concept of gender and used it to make sense of men's life history accounts. She argued that not one kind, but multiple forms of masculinity existed and competed with each other for dominance (Connell 1995). Connell suggested that different kinds of masculinities emerged in everyday life, and the type of masculinity that prevailed as the current "most honoured way of being a man" in any particular locale was "hegemonic" (Connell and Messerschmidt 2005). Thus, certain men had the power to define what was valued masculinity, and other kinds of masculinity were marginalised. In practice, however, scholars frequently used the theory in unanticipated ways, for example, by invoking the idea of static and toxic traits as making up hegemony e.g. stoicism, risk taking, and violence. But hegemony was not intended to be static and toxic, and was always meant to be responsive to social circumstances. Thus, hegemony could potentially appropriate positive values (like emotional intimacy), not just apparently ones considered toxic (Lomas, Cartwright et al. 2015).

Hegemony was envisaged as a powerful ideology shaping men, even if no man could actually live up to its varying (and impossible) expectations (Connell 1995). For example, the instilling of fear in boys (gay or straight) who failed to live up to expectations of heteronormativity (including avoiding "effeminacy" or emotional sensitivity) was thought by Connell to be key to policing masculinity. Certainly, heteronormativity has been a powerful force influencing masculinity. Feminine traits like creativity were not permissible for large swathes of boys in social institutions like schools, lest their heterosexuality be questioned and they risked marginalisation (Plummer 1999). However, heteronormativity is increasingly challlenged. For example, boys in some school settings are beginning to advocate pro-gay attitudes and 
emotional intimacy as part of their masculinity (McCormack and Anderson 2010), although not by any means overturning homophobia. And as intimated above, localised groups of men (e.g. friendship groups, meditation groups) appear to have created new hegemonic values that prize previously marginalised values, like talking about emotions and expressing vulnerability in the company of other men (Creigton and Oliffe 2010, Lomas, Cartwright et al. 2015). Thus, masculine hegemonies are not uniform, they are local, they do not have to be toxic, they can adapt to local conditions, and challenge heteronormativity.

Nevertheless, commentators in the mass media have promoted the idea of globalising, "toxic masculinity", despite the lack of scholarly support for the concept. The \#MeToo movement has highlighted predatory and abusive behaviours against men, first triggered by the allegations made against movie producer Harvey Weinstein in late 2017. Here many social commentators promote the idea of masculinity turning "toxic", a kind of society-wide pathology that infects masculinity (Syed 2016). Connell (1998) herself once tried to develop the idea of a "world gender order," arguing for recognition of a "transnational business masculinity" situated in corporations, to describe men who especially influenced by neoliberal ideals (e.g. privatisation, deregulation). However, this globalising masculinity concept collapsed for want of evidence (Beasley 2008), and Connell (2014) later abandoned the project, finally concluding it was too simplistic (p. 228) "we cannot presuppose a consolidated gender order." While clearly a different concept to toxicity as argued above, Connell's theory of hegemonic masculinities has proliferated exponentially. So much so that hegemonic masculinities had come to dominate discussions of men and gender. Connell's (1995) book, Masculinities, published in 1995 and subsequently updated, had nearly 18,000 Google Scholar citations by mid 2018. Clearly, the concept continues to inspire scholarly thinking. Hearn (2004), for example, has argued that Connell's concept of hegemony does not go far enough in describing and then working to dismantle the dominance of men.

But what about the critiques of hegemony? Connell and Messerschmidt (2005) addressed the critiques over a decade ago, quite rightly pointing out that scholars often misinterpreted the theory. For example, because men frequently seemed to depart from hegemonic ideals in terms of health and help-seeking, some incorrectly saw this as a lack of evidence for hegemony (Reed 2013). Yet the theory specifically allows for such departures: hegemony is not the same thing as traditional masculinity, and it is meant as a yardstick for men to be measured against. And yet, in the fourth decade of its use, cracks in the theory continue. In her "rethinking" piece, Connell summarised 5 main criticisms of the theory (Connell and Messerschmidt 2005):

1. Flaws in the concept of masculinity, e.g. it is a fuzzy and static concept, fixates on heteronormativity, is too essentialist, and is not needed to understand male power anyway.

2. Difficulties translating the hegemony concept to real life, the ambiguity of which Connell admits to, suggesting hegemonies should be seen as ideals only. 
3. Reification - hegemony becomes reduced to toxic traits or simply conflated with patriarchy

4. Being overly social or structural to the point of neglecting the actual subjectivity as experienced by men, which as outlined in this chapter, is hard to deny.

5. As limiting gender to a "self-contained, self-reproducing system", yet Connell points out how hegemony is open to historical change, such as by appropriating gay styles.

Despite the critiques, Connell has argued that what should be retained is the focus on multiple masculinities and the notion of hierarchies. Connell also noted that research around hegemonic masculinity had become disconnected from femininity, including "emphasised" (hegemonic) femininity, and stated that research "now needs to give much closer attention to the practices of women, and the historical interplay of femininities and masculinities... acknowledging the possibility of the democratizing gender relations... it is possible to define a hegemonic masculinity that is thoroughly 'positive'". She also noted subsequently that "... the same masculinities may be simultaneously hegemonic and subordinated..." (Connell 2014). But the theory itself actually discourages conceptual links to "emphasized" femininity, and it encourages a view of unidirectional power from men towards women, and lesser men. Connell herself acknowledges that one problem with hegemonic masculinities is that it tends to separate out (and turn into binaries) the experiences of men and women (Connell and Messerschmidt 2005). Connell admits a kind of uni-directionality in that the concept of hegemony emerged to describe "the pattern of practice ...that allowed men's dominance over women to continue" (Connell and Messerschmidt 2005). However, in an age of intersectionality (see below), unidirectional gendered power on its own cannot make sense of complex social situations. Research continues to accumulate showing that gendered power flows in different directions, and is mediated by other factors like ethnicity.

Some authors have pointed out that the concept of hegemony is vague and unhelpful. For example, does hegemony refer to men at a political level, the most powerful "versions" of men, or groups of everyday men (Beasley 2008)? Beasley suggests that the term should be reserved for use in describing a "political ideal," so as to focus on its "legitimating function" (p. 95). Other authors have questioned even the need for the concept of hegemony at all. Schrock and Schwalbe, for example, (2009) have argued that concepts of multiple masculinities prevents us from properly considering what it is that masculinity. In practice, they also note that plurality in the theory tends to essentialise men into specific categories of masculinity, e.g. as gay or Black masculinities, neglecting in-group variability, which is considerable. The additional problem with the theory is that it draws our attention away from what subjectively is going on for men, because it asks us to filter our answers through a structural theory. One author, for example, has suggested that hegemonic masculinity has tended to obfuscate how men perceive and feel in the world, in favour of more structural and even speculative issues, like globalised masculinity (Whitehead 2002). Other writers like Jefferson (2002) argue that in practice (if not original intent of hegemony), an 'over-socialized' 
view of male subjectivity emerged. What the masculinities debate does show is that even with a strong theory with one origin, different authors interpret in different ways, and varying assessments are made of its usefulness. But what about a concept with different origins, such as 'doing gender'?

\section{Doing Gender}

In more recent decades, the idea of "doing" gender, with similar concepts being "gender performance" or "gender performativity", has been developed in parallel to masculinities, although again there are divergent interpretations of the concept. The idea that gender is "done" by men and women, rather than being traits that we possess, has been advanced since the 1960s. For instance, Harold Garfinkel (1967) studied a young "trans" woman - Agnes who performed and achieved status as a woman before being able to access gender-reassignment surgery. Ervin Goffman subsequently (1977) used a dramaturgical metaphor to show how gender has to be (re)produced in everyday life, such as through the way public toilets were designed and segregated, with a public stage for men to urinate, but with great privacy and luxuries afforded to women. Following on from this early work, Candace West and Don Zimmerman struggled for 10 years to get their now well-regarded 1987 paper on "doing gender" published (it was initially rejected by the top journals). In talking about how they developed their ideas, they acknowledged their debt to Harold Garfinkel but noted that Judith Butler (see below) had not acknowledged their earlier work in developing her notion of gender performativity (West and Zimmerman 2009). They provided a definition of doing gender as "a routine, methodical, and recurring accomplishment. We contend that the "doing" of gender is undertaken by women and men whose competence as members of society is hostage to its production." (p. 126) (1987).

In doing gender, men are compelled to become skilled at acting as "masculine" as defined by society, or face (frequently dire) consequences. Differences between the sexes then become rarefied to reinforce the naturalness of the traits that distinguish men and women. But the important point here is that masculinity is policed with a heavy hand. To illustrate by compelling example, in one South African prison, it was shown how men could rapidly shift status from men to women. Specifically, men who had been raped in prison were considered by other inmates to have undergone a kind of feminine transformation (Gear 2007). Rather than being regarded first and foremost as criminally violated: "In fact, the person who has been raped... is regarded as a woman ... Prisoners will whistle for him as if whistling for a woman... If he mistakenly step[s] on your feet, you will call him 'bitch'." The "doing gender" framework shows how interpretations of gender are complex, requiring other social actors, audiences, and ongoing 'competence' on the part of actors (a requirement they may have no control over). Interestingly, it was also possible in this prison for more dominant men (active in penetration) to take other men as 'wives' (receptive in penetration), and such unions could be considered 'marriages' by other men. Thus, the wider binaries of male/female, active/passive, and heterosexual/homosexual were superimposed on an exclusively homosocial space. While doing gender is at 
once fluid and so allows for variation, it is also rigidly reproductive of the social order due to heavy policing.

By further example, Pascoe (2005) from the University of California studied one particular high school in the US (fictitiously called 'River High'). Boys at River High use the term 'fag' as a vantage point to mark 'outside masculinity', so as to define what masculinity entails (p. 342). Here, boys had to work at trying to rebut a feared label, and to bolster their own masculinity in the eyes of others. There is fluidity here again in that the 'fag' label is usually not permanent, and boys "move in and out of fag positions" (p. 342). Additionally, the tag does not literally mean that the boy is gay, but it does mean the boy has ceased to be considered masculine in a specific situation by particular observers. And here, the way in which masculinity is played out is very much dependent on who is performing. So, while dancing and attention to clothes could attract the label 'fag' for white boys, the same behaviour for Black boys might bolster their manhood. Again, what we are seeing here are masculine identities which emerge through carefully "routinised and managed" spectacles in local settings (Brickell 2006).

While "doing gender" was originally intended to mean conforming to - and subverting - the gender expected of social categories like "man" and "woman" (West and Zimmerman 2009), some argue that the exclusion of the concept of "undoing gender" was an omission. In this way of understanding, social life is thought to become "less gendered" at certain times, where masculine gender may even cease to matter as much. For example, Deutsch (2007) noted 'Female interviewers may have to contend with male interviewees' attempts to reassert male power, but in the end, the interviewer writes the article that defines the interaction between them..." (p. 113). The potential for "undoing" gender happens in unlikely places too, including traditionally male-dominated off-shore oil platforms. Here Ely and Meyerson (2010) discovered how relatively easy it was for men to be "released' from the constraints of masculinity when allowed the opportunity by a powerful institution. With their company heavily involved in promoting collective goals, men became more emotionally connected to others and felt responsible for others' wellbeing. The authors argued that male identities could become much broader than usually allowed by masculinity (p. 27): "organisations equip men to undo gender by giving them the motivation, a model, and a margin of safety to deviate from conventional masculine scripts." Or as one male production operator put it (p. 15), "[We had to be taught] how to be more lovey-dovey and more friendly with each other and to get in touch with the more tender side of each other type of thing."

Once the idea of "doing gender" was established in sociology, Judith Butler's (1990) take on it was that gender was achieved through repetitive and stylised acts that established a fictitiously coherent stable inner 'core' of gendered identity. While the male/female binary that results appears 'natural', Butler drew attention to its intrinsic instability, and the heavy policing required to achieve it. Following on from Foucault (1986), Butler thought that it was through the language available to us that gender came into being and was regulated and normalised. Gender does not so much express an identity, 
rather it reinforces prior conventions already established by available discourses. Famously, Foucault had already argued that the binary division of human sexual expression into heterosexual and homosexual identities developed out of specific legal and medical discourses in the $19^{\text {th }}$ Century. Similarly, Butler was saying that sex (male/female) and gender (men/women) are legitimised by power structures in society, and these are performatively (re)produced. This was a radical (post-structural) position, as she was essentially overturning the idea of a prior gender identity, and instead arguing that gender and sex were "unstable discursive productions" produced through actions (p. 460) (Nayak and Kehily 2006). So, there does not have to be an agent behind the deed, as the deed itself in effect produces the doer. Butler thus (p. 460) "subvert(s) and implodes the very basis of identity itself". Here, the repetitiveness in performativity is inherently unstable, and so there is always the potential for changes to be incorporated into gender (Brickell 2005). The subtle - yet profound - differences in how different theorists understand the doing of gender point to the multiple interpretations of the surface performances that theorists have elaborated.

\section{Manhood acts}

Researchers Douglas Schrock and Michael Schwalbe (2009) in the US did their own stocktake of masculinity, given what they saw as inadequate theorising. They argued that while we know a lot about men in different contexts (e.g. sport, work, health), scholars needed to focus on "manhood acts", defined as "cultural practices that construct women and men as different..." (p. 278). They insisted that manhood acts were about unidirectional power: "aimed at claiming privilege, eliciting deference, and resisting exploitation." Additionally, following on from Goffman, they adopted the dramaturgical idea that the male body itself was important in signifying credible manliness, and so the masculinised identity became a kind of "virtual reality... a consequence of how an actor's appearance and behaviour are interpreted by others" (p. 280). This theory is important, because it focuses our attention on the audience, although the theory (similarly to masculinities) is also unidirectional in terms of power (Ezzell 2012). By way of illustration of manhood acts, Vaccaro et al. (2011) observed power in a mixed martial arts gym, revealing the game like nature of masculinity. They found that although fighters appeared to act with bravery, they were suppressing their anxieties and fears. Fighters feared injury and the intense shame of losing a fight. But fighters must be strategic, developing well worked out plans including: researching opponents on YouTube for vulnerabilities; talking themselves into seeing themselves as superior to their opponents; and trying to psych out their opponents (e.g. by revealing their muscular bodies before a fight). Thus, masculinity is about managing interior vulnerabilities while trying to project a particular kind of manliness. Sumerau (2012) similarly found that gay Christian men played-up elements of dominant masculinity in certain situations to compensate for their deep sense of lack (compensatory manhood acts). For example, men would present themselves as being rational and in control, e.g. "The gay Christian men... constructed compensatory manhood acts in ways that explicitly defined women and other sexual minorities (e.g. promiscuous or effeminate gay men) as inferior beings." While I caution against the notion of unidirectional power, the game 
playing involved, and the activation of masculinity according to circumstances, are central to the conceptualisation of masculinity outlined below.

The concept of "manhood acts" while helpfully refocusing attention on how masculinity is observed, does not discuss the kinds of power that women exercise over men, nor the potential power of marginalised boys and men. For example, in a large mixed-methods study of adolescent romantic relationships in the US, it was found that boys reported less confidence and greater awkwardness than girls in negotiating romantic relations (Giordano, Longmore et al. 2006). One 17 year old Jake talked about the prelude to being dumped as (p. 273), “...I like talked to her on the phone, I don't know it was kind of awkward, like long silences... I couldn't like think of anything more to say you know..." The authors expressed surprise that while boys make more attempts to influence girls, it was the boys who reported greater levels of actually being influenced by their romantic partner. In terms of perceived power, boys also suggest they have less capability in the face of girls decision-making power. As David, 18, said (p. 281), “...I guess I wasn't on her level you know because she wanted to do it [have sex] more than I did... I was scared, I didn't know what I was doing..." Research commonly focuses on how men control condom use and non-use, but in one study, one young man said about condoms, "I really didn't have much of a say in this anyways, because she said she didn't like condoms period... for the longest time I never used condoms... but I wanted to..." (Devries and Free 2010). Men may have good reasons to use condoms (e.g. to avoid fatherhood), but can feel pressured to not use them just like women (Bowleg 2004).

There is also the democratising of sexual relations among younger men and women. Here, some - but not all - elements of the double standard (sexually experienced boys as "studs", girls as "sluts") are being challenged. For example, a study of US undergraduate college students presented a scenario of a heterosexual hook-up (casual sex) at a party, followed by a date.

Students generally were relaxed about women desiring men and having enough sexual agency to hook-up after a party (Reid, Elliott et al. 2011). It was only afterwards, if the hook-up does or does not turn into a date/potential relationship, that women were judged more harshly than men (p. 564): "Women are allowed to have fun at parties, but once it becomes a serious matter, traditional gender norms, which affirm men's prerogatives, take precedence". In another study that surveyed attitudes of college students online, it was found that 3 in 4 students do not subscribe to different standards when it comes to males and females hooking up, although men were more likely to hold double standards (Allison and Risman 2013). And while it is now possible for women to take initiative in proposing marriage, or to assert the desirability of co-habiting, men still have more control over whether a fledgling relationship is formalised (Sassler and Miller 2011). This kind of deeper research does not easily fit common narratives in the scholarly literature about uni-directional gendered power.

\section{Erotic capital and sexual relations}

If we are to begin to understand masculinity as spectacle, and as something that can be activated, undone or lie dormant, then eroticism is an over-looked 
issue, as intimated at the start of the chapter. Positioning eroticism as an powerful asset, it is not hard to understand why many feminist scholars would be annoyed with Catherine Hakim's analysis (2010). Harim argues that men have exploited patriarchal power in academia to prevent a proper examination of erotic capital, and feminists may have unwittingly colluded on moral grounds. Hakim claims that women have long nurtured and exploited erotic capital, frequently with access to (p. 499) "greater erotic appeal than men." Hakim outlines the elements of erotic capital including cultural ideas of facial beauty, bodily sexual attractiveness, social skills (e.g. flirting, developing emotional connections), liveliness/energy, presentation (e.g. fashion), and sexuality (e.g. sexual competence). Hakim firmly situates her theory of erotic capital in the doing of gender realm, acknowledging that both men and women who master the art of erotic capital can create distinct advantages for themselves.

Hakim's view, of course, is even more controversial in the \#MeToo era, and there were critics beforehand. For example, it was argued that the concept of erotic capital is not new, that it over-reaches, and ignores the contexts in which it operates, such as the way that women have less power and become relatively less desirable than men as they age (Green 2013). Men on the other hand can take up desired positions as they age, like the "silver fox". Yet, erotic capital has to be acknowledged as a possible source of power for both women and men, however fragile. Masculinity is an erotic currency which gay men, for example, are well versed in (Ridge 2004). So much so, that it is argued that (self and other) pornography has become the centre-piece of global gay culture in the era of social apps like Grindr (Tziallas 2015). However, as with women, there are pitfalls for men who demonstrate erotic capital. For example, men considered "handsome" may suffer in terms of their job prospects in certain kinds of professions e.g. intellectual (Udry and Eckland 1984). While arguments put forward by scholars like Hakim are controversial in the current climate, the interesting emphasis on the audience, less obvious forms of power, warrants attention.

\section{Intersectionality}

One problem of focusing on masculinity in relative isolation is that it can reify differences between men and women, while downplaying similarities (Springer, Hankivsky et al. 2012). Additionally, there are a range of dimensions on which we may be different or the same besides gender, including (p. 1661) "race/ethnicity, Indigeneity, gender, class, sexuality, geography, age, disability/ability, migration status, religion) and forms of systemic oppression (e.g., racism, classism, sexism, ableism, homophobia)." If we are oppressed or privileged, it may be for complex reasons. On a day to day basis, and depending on circumstances, men and women negotiate varying identities and social memberships, including gender positioning, social class, occupation, and ethnicity. Intersectionality is about the notion of ( $p$. 1661) "simultaneous intersections between aspects of social difference and identity (e.g., as related to meanings of race/ethnicity, Indigeneity, gender, class, sexuality, geography, age, disability/ability, migration status, religion)" (Springer, Hankivsky et al. 2012). It's an idea that has caused debate 
between feminists, including on social media, with some white middle-class feminists accused of lack of awareness of their own privileged positions and unconscious racism (Adewunmi 2012). Black women argue that discrimination is becoming increasingly specialised even if white women have won certain privileges (Williams 2013). In terms of masculinity, intersectionality could be seen to further question the value of focusing specially on social wide system of masculinities which are ring-fenced from other considerations. Coston and Kimmel (2012) , for example, see privilege as uneven when it comes to men, affected by things such as disability, sexuality and class. They point to some of the strategies men might use to deal with their particular level of power (or lack thereof), such as exaggeration (think of very camp gay men), normalisation (we are just like you who have privilege), and militant chauvinism (where dominant groups claim superiority).

One study of US Black heterosexual men of low income uncovered intersecting social forces that created challenges for men, variously described as 'the struggle' (Bowleg, Teti et al. 2013). Or as Paul, a college graduate in his 30s said, "... to have less access to the system and ... to work harder to get like results that maybe Caucasians, or people that come from higher economic backgrounds [readily get is] kind of depressin." The men talked about micro-aggressions they experienced everyday due to their race, for example, Sean noted at work "White people get to come in late, and you know, feel what they feel, but we [Black employees] get written up for certain things [that the White employees would not get written up for]." There is also the well-documented system of surveillance and harassment (Colebrook 2010)m law enforcement that Black men experience over and above white men. As Wayne put it, "And it happens over and over ... Just getting the one over [by police], just being harassed by cops [who are] always looking [at me] like I'm suspicious ... like a suspect or something, a crim[inal] or something." Thus the lower-income black male experience is qualitatively different from that experienced by white men. Black men are engaged in a different game, it involves masculinity, but there are different dynamics and rules, not different masculinities.

\section{Towards masculinity as spectacle and game}

As Mac an Ghaill and Haywood (2012) argue, scholarly work often ends up adopting a "simple gendered frame based upon singular categories of male and female", constructing men as "damaged and damage doing". Men are seen as not only toxic towards themselves, but especially hazardous for women, who generally figure as widely disempowered as well as innocent in this narrative. This binary split of "women good/men bad" tends to disconnect gender theory from the everyday complexity of life, where everyone has limitations, and women may also be toxic (Klein 1950, Colebrook 2010). The above narrative also risks alienating men who subsequently cannot relate to what feminist scholars talk about. Additionally, the combativeness and disconnection between theoretical discussions and the daily lives of men risks male subjectivity only be acceptable through particular filters that allow some experiences but not others. This situation was clearly never the intention of Connell and other scholars. But just as Connell delivered a devastating blow to sex role theory in the 80 s, hegemony is also increasingly challenged. So 
much so, scholars are already talking about a post-hegemonic world. But what might replace hegemony is confusing, since masculinity appears to be in the eye of the beholder. As outlined above, masculinity has essentially become what different theorists and their tribes say it is.

Authors pronouncing the death of hegemony have tried to assert their own ideas. "Manhood acts", for example, conceptualises masculinity in terms of power exercised by more powerful men. Anderson and colleagues, on the otherhand, take an entirely post-feminist path, and talk about "inclusive masculinity", arguing that as the fear surrounding homosexuality has declined in the West, so too masculinity has softened and become more egalitarian (Anderson and McCormack 2014). While the authors put forward some striking qualitative evidence for this softening (e.g. increasing physical and emotional affections between heterosexual men), it has been argued that this "cheery" optimistic narrative also represents a return to conservative sexual politics, where patriarchy remains very much intact (O'Neill 2015). Further, inclusive masculinity is thought to overlook the privileges (power) that allow some heterosexual men to engage in homoerotic practices with latitude. But just as masculinity is not necessarily the same thing as unidirectional power (as argued in this chapter), masculinity is more than what is organised around levels of hysteria about one issue (homosexuality).

In this chapter, I took some time to examine hegemony and plurality in masculinities, explaining how these ideas have been questioned of late. It turns out that hegemony is shifting and difficult to pin down, made all the more difficult by the multiple ways in which different scholars have interpreted and operationalised the theory. Hegemony also tends to focus our attention on social wide structures and away from men and their subjective worlds, regardless of the original intentions of the theory. The theory also invites us to consider masculinity in isolation, even from femininity, focusing attention on gendered power as masculine and unidirectional (men do things to women and less powerful men). It is not specifically designed to conceptualise the democratisation of gender, nor instances where woman hold power over men, such as when women demonstrate superior relational abilities. Thus, it not only encourages us to apply an overarching structural framework to interpret male subjectivities, but it also invites us to turn a blind eye to those dynamics that do not fit the theory. The concept also focuses us on differences between groups of men, or between men and women, rather than the complex interplay of difference, privilege and disadvantage, such as negotiated by Black men every day.

The ideas of gender as something that is done rather than static, actively produced in everyday life, a position to take up, or an aesthetic, are now taken for granted by many scholars. But overlook is the idea that gender is variously interpreted, so it can be undone, it can more or less important. Until now, it was generally considered that men are operating within considerable restraints set by the gendered order of society. That societies more or less agreed about acceptable performances of masculinity. But even the idea of brutal policing of gender is beginning to be questioned, as in the theory of inclusive masculinity above. Certainly, the idea that marginalised masculinity is a useful concept, or that marginalised men are really marginalised is 
questioned by some scholars (Tischler and McCaughtry 2011). Additionally, some scholars are now exploring the power that (at least privileged white, middle-class Western) women can wield. Masculinity is a site of contestation, and it is a public spectacle that the audience has a say in (as evident in the way scholars cannot agree, but nevertheless put forward theories of masculinity).

As outlined in this chapter, masculinity also needs to be understood as something that is experienced and performed from within bodies. While the body itself is a powerful indicator of masculinity to many audiences, masculinity still has to be performed, and the virtual (masculine) self must be observed by others. And despite the best efforts of gendered performances, judgements about masculinity reside with the observer. It is not that there are multiple masculinities, but multiple interpretations of masculinity, as is obvious now scoping the scholarly literature. Masculinity is in the eye of the beholder, and the audience itself has all kinds of investments in masculinity. For instance, does the audience member notice bodies, eroticism, charisma, the social structures supporting gender, the power of men, or the power of women, or a mix of all these? Do they imagine toxicity or benevolence? A conceptual framework of doing, undoing and multiple interpretations of masculinity (not just based on unidirectional power) needs to be captured in new understandings of masculinity. Additionally, a level of knowingness about the masculinity game, especially among men, is also important. Masculinity does not ultimately reside in a social system, or an individual, but in the inevitable variation in interpretations of that masculinity, and the way its importance waxes and wanes.

Said in another way, masculinity has to be willed into being, it has to be activated, and context is important here. Hitherto, the degree to which masculinity is a matter of personal taste, and multiple interpretations, has been neglected. As Frank and colleagues (Frank, Kehler et al. 2003) noted about gender over a decade ago, "we need to think differently about ... how we have come to 'know' the world through the more general artificial polarities which modern investigation and theorising has invented as 'real'." Ideas of audience and contested interpretations, and concepts like gamification are ways of reconfiguring masculinity away from the power of those who tell us what masculinity is, towards better understanding the (necessarily) different readings of masculinity. The gamification of masculinity can most easily be seen when men perform a masculinity but realise at some level that it is inauthentic. In the US, a study of formerly incarcerated Latino men who transition from being "knuckleheads" (i.e. "knowingly acting in ways that are harmful or risky" (p. 1765)) to responsible, community minded men is a good example (Muñoz-Laboy, Perry et al. 2012). Knuckleheads take up the bad boy persona for benefits like short-term gain in money and status (winning). Postprison though, knuckleheads say they actually feel lonely and isolated, and risk re-engaging with crime to deal with their subjectively difficult feelings. But with support, men can become more reflective and empowered enough to feel that they can be more authentic and nurturing (self and other). Like Pedro, who decided to prioritise his family above his previous street life (p. 1771): "My way hurt me too much. My way never took no where different. I no longer 
feared the pains of change because my pain of remaining the same became greater than the pains of change. I vowed to fight against the feelings of loneliness. My life still had a chance and nothing or anyone would take it from me again." Somewhere beneath the masculine veneer is a real person with a subjectivity just like you and I.

\section{Conclusion}

It is not surprising we have reached a point where different scholars - whether masculinity scholars, feminists, or those in the men's movement - have widely differing ideas about masculinity. Masculinity might be "done" by men, but it is interpreted and assessed by others in different ways. And as in any review of a performance, is it not the point that perspectives will differ? The audience for any potentially gendered spectacle differs, and observers can be very particular about what resonates for them. Like movie critics, there will always be disagreements, although there will be some level of agreement about the movie. Is it a good, bad or mediocre performance? At the same time, over the decades, particularly in light of great feminist advances, we have become much more ambivalent about the "masculinity game". The reactions to displays of masculinity range from admiration, all the way through to disgust and repulsion. Is it not the point of masculinity to evoke feelings in us, the audience? Because we still tend to locate masculinity in the individual or the social system (depending on our leaning), we have less awareness of our role in curating masculinity. Masculinity is a social rather than individual accomplishment, but one that requires the full range of actors, producers, directors and audiences.

\section{REFERENCES}

- $\quad$ Adewunmi, B. (2012, 8th October). "What the Girls spat on Twitter tells us about feminism." The Guardian Retrieved March 31st, 2014, from http://www.theguardian.com/commentisfree/2012/oct/08/girls-twitterfeminism-caitlin-moran.

- $\quad$ Allison, R. and B. J. Risman (2013). "A double standard for "Hooking Up": How far have we come toward gender equality?" Social Science Research 42(5): 1191-1206.

- $\quad$ Anderson, E. and M. McCormack (2014). "Cuddling and Spooning: Heteromasculinity and Homosocial Tactility among Student-athletes." Men and Masculinities.

- $\quad$ Annandale, E. and J. Clark (1996). "What is gender? Feminist theory and the sociology of human reproduction." Sociology of Health \& IIIness 18(1): 17-44.

- $\quad$ Beasley, C. (2008). "Rethinking Hegemonic Masculinity in a Globalizing World." Men and Masculinities 11(1): 86-103.

- $\quad$ Bowleg, L. (2004). "Love, Sex, and Masculinity in Sociocultural Context." Men and Masculinities 7(2): 166-186.

- $\quad$ Bowleg, L., M. Teti, D. J. Malebranche and J. M. Tschann (2013). "'It's an uphill battle everyday": Intersectionality, low-income Black heterosexual men, and implications for HIV prevention research and interventions." Psychology of men \& masculinity 14(1): 25-34. 
- $\quad$ Brickell, C. (2005). "Masculinities, Performativity, and Subversion: A Sociological Reappraisal." Men and Masculinities 8(1): 24-43.

- $\quad$ Brickell, C. (2006). "The sociological construction of gender and sexuality." The Sociological Review 54(1): 87-113.

- $\quad$ Butler, J. (1990). Gender Trouble. New York, Routledge.

- $\quad$ Chu, J. Y. (2005). "Adolescent boys' friendships and peer group culture." New Directions for Child and Adolescent Development 2005(107): 722.

- $\quad$ Colebrook, C. (2010). "Toxic Feminism: Hope and Hopelessness after Feminism." Journal for Cultural Research 14(4): 323-335.

- $\quad$ Connell, R. (2014). "Margin becoming centre: for a world-centred rethinking of masculinities." NORMA 9(4): 217-231.

- $\quad$ Connell, R. W. (1987). Gender \& Power. Cambridge, Polity Press.

- $\quad$ Connell, R. W. (1995). Masculinities. St. Leonards, N.S.W, Allen \& Unwin.

- $\quad$ Connell, R. W. (1998). "Masculinities and Globalization." Men and Masculinities 1(1): 3-23.

- $\quad$ Connell, R. W. and J. W. Messerschmidt (2005). "Hegemonic Masculinity: Rethinking the Concept." Gender Society 19(6): 829-859.

- $\quad$ Coston, B. M. and M. Kimmel (2012). "Seeing Privilege Where It Isn't: Marginalized Masculinities and the Intersectionality of Privilege." Journal of Social Issues 68(1): 97-111.

- $\quad$ Creigton, G. and J. L. Oliffe (2010). "Theorizing masculinities and men's health: A brief history with a view to practice." Health Sociology Review 19(4): 409-418.

- $\quad$ Crimp, D. (1999). "Getting the Warhol We Deserve." Social Text(59): 49-66.

- $\quad$ Deutsch, F. M. (2007). "Undoing Gender." Gender \& Society 21(1): 106-127.

- $\quad$ Devries, K. M. and C. Free (2010). "'I told him not to use condoms': masculinities, femininities and sexual health of Aboriginal Canadian young people." Sociology of Health \& Illness 32(6): 827-842.

- $\quad$ Ely, R. J. and D. E. Meyerson (2010). "An organizational approach to undoing gender: The unlikely case of offshore oil platforms." Research in Organizational Behavior 30(0): 3-34.

- $\quad$ Ezzell, M. B. (2012). "'I'm in Control" : Compensatory Manhood in a Therapeutic Community." Gender \& Society.

- $\quad$ Farrell, W. (1993). The myth of male power: Why men are the disposable sex. New York, Simon \& Schuster.

- $\quad$ Foucault, M. (1986). The History of Sexuality. Harmondsworth, Penguin.

- $\quad$ Frank, B., M. Kehler, T. Lovell and K. Davison (2003). "A Tangle of Trouble: Boys, masculinity and schooling--future directions." Educational Review 55(2): 119-133.

- Garfinkel, H. (1967). Studies in Ethnomethodology. Englewood Cliffs, Prentice-Hall.

- Gear, S. (2007). "Behind the Bars of Masculinity: Male Rape and Homophobia in and about South African Men's Prisons." Sexualities 10(2): 209-227. 
- Giordano, P. C., M. A. Longmore and W. D. Manning (2006). "Gender and the Meanings of Adolescent Romantic Relationships: A Focus on Boys." American Sociological Review 71(2): 260-287.

- $\quad$ Goffman, E. (1977). "The arrangement between the sexes." Theory and Society 4(3): 301-331.

- $\quad$ Gorman-Murray, A. (2013). "Urban Homebodies: Embodiment, Masculinity, and Domesticity in Inner Sydney." Geographical Research 51(2): 137-144.

- $\quad$ Graham, M. (1998). "Identity, Place, and Erotic Community Within Gay Leather Culture in Stockholm." Journal of Homosexuality 35(3-4): 163-183.

- $\quad$ Gramsci, A. (1998). "Hegemony." Literary Theory: An Anthology. Malden, Blackwell.

- $\quad$ Green, A. I. (2013). "'Erotic capital' and the power of desirability: Why "honey money' is a bad collective strategy for remedying gender inequality." Sexualities 16(1-2): 137-158.

- Hakim, C. (2010). "Erotic Capital." European Sociological Review 26(5): 499-518.

- $\quad$ Harrison, L. A. and A. B. Lynch (2005). "Social Role Theory and the Perceived Gender Role Orientation of Athletes." Sex Roles 52(3): 227-236.

- Hearn, J. (2004). "From Hegemonic Masculinity to the Hegemony of Men." Feminist Theory 5(1): 49-72.

- Jefferson, T. (2002). "Subordinating hegemonic masculinity." Theoretical Criminology 6(1): 63-88.

- $\quad$ Kadir, H. A. (2012). "School Gangs of Yogyakarta: Mass Fighting Strategies and Masculine Charisma in the City of Students." The Asia Pacific Journal of Anthropology 13(4): 352-365.

- Klein, M. (1950). "On the criteria for the termination of a psychoanalysis." The International Journal of Psychoanalysis 31: 78-80.

- $\quad$ Lamont, M., B. Y. Park and E. Ayala-Hurtado (2017). "Trump's electoral speeches and his appeal to the American white working class." The British Journal of Sociology 68: S153-S180.

- $\quad$ Levant, R. F., K. Richmond, R. G. Majors, J. E. Inclan, J. M. Rossello, M. Heesacker, G. T. Rowan and A. Sellers (2003). "A multicultural investigation of masculinity ideology and alexithymia." Psychology of Men \& Masculinity 4(2): 91-99.

- $\quad$ Lomas, T., T. Cartwright, T. Edginton and D. Ridge (2013). "I was so done in that I just recognized it very plainly, "You need to do something"': Men's narratives of struggle, distress and turning to meditation." Health: 17(2): 191-208.

- $\quad$ Lomas, T., T. Cartwright, T. Edginton and D. Ridge (2015). "New Ways of Being a Man: "Positive" Hegemonic Masculinity in Meditation-based Communities of Practice." Men and Masculinities.

- $\quad$ Mac an Ghaill, M. and C. Haywood (2012). "Understanding boys':

Thinking through boys, masculinity and suicide." Social Science \& Medicine 74(4): 482-489.

- $\quad$ McClelland, J. (2002). "Eros and Sport: A Humanist's Perspective." Journal of Sport History 29(3): 395. 
- $\quad$ McCormack, M. and E. Anderson (2010). "'It's Just Not Acceptable Any More": The Erosion of Homophobia and the Softening of Masculinity at an English Sixth Form." Sociology 44(5): 843-859.

- $\quad$ Muñoz-Laboy, M., A. Perry, I. Bobet, S. Bobet, H. Ramos, F. Quiñones and K. Lloyd (2012). "The "knucklehead" approach and what matters in terms of health for formerly incarcerated Latino men." Social Science \&amp; Medicine 74(11): 1765-1773.

- $\quad$ Nayak, A. and M. J. Kehily (2006). "Gender undone: subversion, regulation and embodiment in the work of Judith Butler." British Journal of Sociology of Education 27(4): 459-472.

- O'Neill, R. (2015). "Whither Critical Masculinity Studies? Notes on Inclusive Masculinity Theory, Postfeminism, and Sexual Politics." Men and Masculinities 18(1): 100-120.

- $\quad$ Pascoe, C. J. (2005). "'Dude, You're a Fag': Adolescent Masculinity and the Fag Discourse." Sexualities 8(3): 329-346.

- $\quad$ Plummer, D. (1999). One of the Boys. New York, Haworth Press.

- $\quad$ Potts, A. (2000). "'The Essence of the Hard On": Hegemonic Masculinity and the Cultural Construction of "Erectile Dysfunction"." Men and Masculinities 3(1): 85-103.

- $\quad$ Reed, K. (2013). "Beyond Hegemonic Masculinity: The Role of Family Genetic History in Men's Accounts of Health." Sociology 47(5): 906-920.

- $\quad$ Reid, J. A., S. Elliott and G. R. Webber (2011). "Casual Hookups to Formal Dates: Refining the Boundaries of the Sexual Double Standard." Gender \& Society 25(5): 545-568.

- $\quad$ Ridge, D. (2004). "'It was an Incredible Thrill': The Social Meanings and Dynamics of Younger Gay Men's Experiences of Barebacking in Melbourne." Sexualities 7(3): 259-279.

- $\quad$ Sassler, S. and A. J. Miller (2011). "Waiting to Be Asked: Gender, Power, and Relationship Progression Among Cohabiting Couples." Journal of Family Issues 32(4): 482-506.

- $\quad$ Schrock, D. and M. Schwalbe (2009). "Men, Masculinity, and Manhood Acts." Annual Review of Sociology 35(1): 277-295.

- $\quad$ Siegel, M. (2003). "Doing It for Andy." Art Journal 62(1): 7-13.

- $\quad$ Springer, K. W., O. Hankivsky and L. M. Bates (2012). "Gender and health: Relational, intersectional, and biosocial approaches." Social Science \&amp; Medicine 74(11): 1661-1666.

- $\quad$ Steinberg, P. E., S. Page, J. Dittmer, B. Gökariksel, S. Smith, A. Ingram and N. Koch (2018). "Reassessing the Trump presidency, one year on." Political Geography 62: 207-215.

- $\quad$ Stemple, L. (2008). "Male Rape and Human Rights." Hastings Law Journal 60: 605-647.

- $\quad$ Sumerau, J. E. (2012). "“That's What a Man Is Supposed to Do"." Gender \& Society 26(3): 461-487.

- $\quad$ Syed, H. (2016). "The Shooting in Orlando, Terrorism or Toxic Masculinity (or Both?)." Men and Masculinities 19(5): 555-565.

- $\quad$ Tischler, A. and N. McCaughtry (2011). "PE Is Not for Me." Research Quarterly for Exercise and Sport 82(1): 37-48.

- Tziallas, E. (2015). "Gamified Eroticism: Gay Male "Social Networking" Applications and Self-Pornography." Sexuality \& Culture 19(4): 759-775. 
- $\quad$ Udry, J. R. and B. K. Eckland (1984). "Benefits of being attractive:

Differential payoffs for men and women." Psychological Reports 54(1): 47-56.

- Vaccaro, C. A., D. P. Schrock and J. M. McCabe (2011). "Managing Emotional Manhood: Fighting and fostering fear in mixed martial arts." Social Psychology Quarterly 74(4): 414-437.

- $\quad$ West, C. and D. H. Zimmerman (1987). "Doing Gender." Gender and Society 1(2): 125-151.

- $\quad$ West, C. and D. H. Zimmerman (2009). "Accounting for doing gender." Gender and Society 23(1): 112-122.

- Whitehead, S. M. (2002). Men and masculinities: Key themes and new directions. Cambridge, Polity Press.

- Wienke, C. (1998). "Negotiating the Male Body: Men, Masculinity, and Cultural Ideals." The Journal of Men's Studies 6(3): 255-282.

- $\quad$ Williams, Z. (2013, 18th April). "Are you too white, rich, able-bodied and straight to be a feminist?" The Guardian Retrieved 31st March, 2014, from http://www.theguardian.com/commentisfree/2013/apr/18/are-youtoo-white-rich-straight-to-be-feminist. 